\title{
Article 5 of the ECHR and 28-day pre-charge detention of terrorist suspects
}

\author{
BRICE DICKSON
}

\author{
Queen's University Belfast*
}

\begin{abstract}
Introduction
$\mathrm{U}$ nder the Terrorism Act 2006, a person who has been arrested in the UK on reasonable suspicion of involvement in terrorism can be detained in custody for up to 28 days without being charged with any particular offence. In 2008, the government tried to extend the maximum detention period to 42 days, but a heavy defeat in a vote in the House of Lords prompted it to abandon that proposal, or at least to put it in cold storage. Two years earlier the government had even tried to argue for a maximum period of 90 days, but on that occasion severe opposition from its own backbenchers in the House of Commons forced it to compromise on 28 days.

At the time of these debates, assertions were often made within and without Parliament that a particular maximum period would or would not breach the European Convention on Human Rights (ECHR). The purpose of the present article is to examine that particular issue more closely. It seeks to show that, uncomfortable though it may be for those who hope to find in Convention language and jurisprudence a firm guarantee against lengthy pre-charge detention, the right to liberty as currently understood by the European Court of Human Rights does not embrace the right not to be detained for longer than a specified period prior to being charged. Provided other conditions are satisfied, the European Court seems able to tolerate quite lengthy detentions, especially in terrorist cases. Current UK law enables those other conditions to be satisfied, though of course whether they are or not in any particular case will always depend on the pertinent facts of the particular case.
\end{abstract}

\section{Pre-charge detention law for terrorist suspects in the United Kingdom}

The detention regime for persons arrested in the United Kingdom on reasonable suspicion of involvement in terrorist activities differs significantly from that for non-terrorist suspects. ${ }^{1}$ The police can initially detain terrorist suspects for 48 hours, ${ }^{2}$ not just for the 24 or (if authorised by a senior officer) 36 hours allowed for non-terrorist suspects. During that

* Professor of International and Comparative Law and Director of the Human Rights Centre, School of Law, Queen's University Belfast. I am grateful to Dr Gordon Anthony for comments on an earlier draft of this piece. Errors remaining are mine alone.

1 See, generally, M Zander, The Police and Criminal Evidence Act 1984 5th edn (London: Sweet \& Maxwell 2005), pp. 133-92.

2 Terrorism Act 2000, s. 41(3). 
48-hour period the detention must, as in non-terrorist cases, be periodically reviewed, but the first review has to be carried out "as soon as is reasonably practicable after the time of the person's arrest" 3 (rather than within six hours) and later reviews are due at intervals of not more than 12 hours ${ }^{4}$ (rather than nine). As in non-terrorist cases, reviews can be postponed if one of three conditions is satisfied. ${ }^{5}$ If none of those conditions is satisfied but a review is still not carried out when required, the detention automatically becomes unlawful, entitling the detainee to damages for false imprisonment, but not to immediate release. ${ }^{6}$

A review officer can authorise the continued detention of a terrorist suspect not only if either of the two grounds applicable in non-terrorist cases applies - namely that the review officer is satisfied that continued detention is necessary to preserve relevant evidence or to obtain such evidence by questioning the detainee or otherwise ${ }^{7}-$ but also if one of five additional grounds applies. Three of these additional grounds relate to situations where the detainee might be deported and they will not be examined further here. ${ }^{8}$ The other two are where the review officer is satisfied that continued detention is necessary to await the result of an examination of relevant evidence or of anything the examination of which is being carried out with a view to obtaining relevant evidence, ${ }^{9}$ or to await a decision whether or not to charge the detainee with an offence. ${ }^{10}$ In all seven situations, with one exception, the review officer also has to be satisfied that the investigation or process in question is being conducted diligently and expeditiously. ${ }^{11}$ Remarkably, the exception relates to where detention is extended pending the result of an examination of relevant evidence or of anything the examination of which is being carried out with a view to obtaining relevant evidence. ${ }^{12}$ As in non-terrorist cases, the review officer must give the detainee or his or her solicitor an opportunity to make oral or written representations ${ }^{13}$ and must supply the

3 Terrorism Act 2000, Sch. 8, para. 21(2).

4 Ibid. Sch. 8, para. 21(3).

5 Ibid. Sch. 8, para. 22(1). The conditions are: (a) that it is not practicable to carry out the review at the time, (b) that the detained person is being questioned by a police officer and the review officer is satisfied that an interruption of the questioning to carry out the review would prejudice the investigation in connection with which the person is being questioned, and (c) that no review officer is readily available.

6 Roberts v Chief Constable of the Cheshire Constabulary [1999] 2 All ER 326 (CA). This was not a case involving a terrorist suspect, but it is submitted that its ratio decidendi covers terrorist cases too.

7 Terrorism Act 2000, Sch. 8, paras 23(1)(a) and (b). For non-terrorist suspects the wording of the relevant law is slightly different, but not materially so: see Police and Criminal Evidence Act 1984 (the PACE legislation), s. 40(8), incorporating by reference s. 37(2) and (3).

8 Terrorism Act 2000, Sch. 8, paras 23(1)(c), (d) and (e). There are no equivalent provisions in the PACE legislation for non-terrorist suspects.

9 Terrorism Act 2000, Sch. 8, para. 23(1)(ba), inserted by the Terrorism Act 2006, s 24(1). There is no equivalent in the PACE legislation.

10 Terrorism Act 2000, Sch. 8, para. 23(1)(f). This too has no equivalent in the PACE legislation. Potentially it could lead to the Kafkaesque position where a terrorist suspect is lawfully detained without charge just because the police are dithering over whether to lay such a charge.

11 Terrorism Act 2000, Sch. 8, paras 23(2) and (3). Strangely, this is never an explicit requirement in nonterrorist cases.

12 When this ground for extended detention was introduced in 2006 (see n. 9 above) no provision was made for subjecting it to the additional conditions provided for in Sch. 8, paras 23(2) and (3), and no justification for the omission appears to have been given to Parliament during the debates on the Bill. The omission cannot be justified on the basis that forensic examinations are outside the control of the police, because at least one other "process" outside the control of the police (viz. a decision by the Home Secretary whether to serve a deportation order on the detainee) does have to be conducted diligently and expeditiously: see Sch. 8 , para. 23(3) as it relates to para. 23(1)(e). Moreover, the requirement for diligence and expedition applies when applications are made to extend detention beyond 48 hours (see the text corresponding to n. 20 below).

13 Terrorism Act 2000, Sch. 8, para. 26. 
detainee with a written record of the outcome of the review, made (unless there are special circumstances) ${ }^{14}$ in his or her presence. ${ }^{15}$

If the police wish to prolong a terrorist suspect's detention beyond 48 hours they have to apply to "a judicial authority" for a warrant of further detention. ${ }^{16}$ A prosecutor can also now make such an application. ${ }^{17}$ In England and Wales the relevant judicial authority is a senior district judge (Chief Magistrate) or his or her designated deputy, in Scotland it is a sheriff, and in Northern Ireland it is a county court judge or a designated resident magistrate. ${ }^{18}$ The judicial authority can then grant one or more warrants of further detention bringing the maximum detention period up to seven days, but can do so only if satisfied that there are reasonable grounds for believing that the further detention of the detainee is necessary to obtain relevant evidence whether by questioning the detainee or otherwise, to preserve relevant evidence, or pending the result of an examination of any relevant evidence or of anything the examination of which is being carried out with a view to obtaining relevant evidence. ${ }^{19}$ The judicial authority must also be satisfied that the investigation in connection with which the detainee has been detained is being conducted diligently and expeditiously. ${ }^{20}$ The other four grounds which can justify the review officer in authorising detention up to 48 hours no longer apply at this stage. Thereafter, the police or prosecution can apply to the judicial authority for one or more additional warrants of further detention, in chunks of no more than seven days, until a total of 28 days has elapsed since the detainee's arrest, ${ }^{21}$ but such warrants can be issued for detentions lasting beyond the first 14 days only by "a senior judge", 22 which means a judge of the High Court or, in Scotland, of the High Court of Justiciary. ${ }^{23}$ One of the consequences of involving judges of this level is that their decisions cannot be judicially reviewed. ${ }^{24}$

Originally the maximum pre-charge detention period for terrorist suspects - laid down by the Prevention of Terrorism (Temporary Provisions) Act 1974 - was seven days, but the power to extend the detention from 48 hours to that maximum was entrusted at that time not to a judicial authority but to a Secretary of State. ${ }^{25}$ The power was not transferred to a

14 Terrorism Act 2000, Sch. 8, para. 28(3).

15 Ibid. Sch. 8, para. 28(1) and (2).

16 Ibid. Sch. 9, para. 29.

17 Ibid. as amended by Terrorism Act 2006, s. 23(2).

18 Terrorism Act 2000, Sch. 8, para. 29(4). The designating authority for both England and Wales and Northern Ireland is the Lord Chancellor.

19 Ibid. Sch. 8, para. 32(1)(a) and (1A), the latter having been inserted by the Terrorism Act 2006, s. 24(3).

20 Terrorism Act 2000, Sch. 8, para. 32(1)(b).

21 Ibid. Sch. 8, para. 36(3), as substituted by the Terrorism Act 2006, s. 23(7).

22 Terrorism Act 2000, Sch. 8, para. 36(1A) and (1B), inserted by the Terrorism Act 2006, s. 23(6).

23 Terrorism Act 2000, Sch. 8, para. 36(7), inserted by Terrorism Act 2006, s. 23(10).

24 R (Hussain) v Hon. Mr Justice Collins [2006] EWHC 2467 (Admin).

25 Prevention of Terrorism (Temporary Provisions) Act 1974, s. 7(2). In Brogan v UK (1989) 11 EHRR 117 the European Court of Human Rights held that the equivalent provision in the 1989 version of this Act (s. 14(5)) was in breach of Article 5(3) of the ECHR because it prevented an arrested person from being "brought promptly before a judge or other officer authorised by law to exercise judicial power". Immediately thereafter the UK government submitted a new notice of derogation to the Council of Europe claiming that, because of the troubles in Northern Ireland, there was a "public emergency threatening the life of the nation" and that a government minister, not a judge, was therefore the appropriate person to decide whether pre-charge detention for up to seven days should be allowed. In Brannigan and McBride v UK (1993) 17 EHRR 539, the European Court of Human Rights upheld the validity of that notice of derogation, saying that the power to deprive detainees of any access to a judicial officer for seven days was a proportionate and otherwise acceptable response to what was indeed an emergency. The derogation was still valid in the eyes of the European Court several years later: see Marshallv United Kingdom App. No. 41571/98, decision of 10 July 2001. 
judicial authority until the entry into force of the Terrorism Act 2000 in February 2001.26 The Anti-terrorism, Crime and Security Act 2001 left the maximum detention period unaltered, although it did set up an indefinite detention system for non-British nationals which was later found by both the House of $\operatorname{Lords}^{27}$ and the European Court of Human Rights $^{28}$ to be in breach of Article 5 of the ECHR, even though the UK government had again entered a notice of derogation under Article 15. ${ }^{29}$ The seven-day maximum was, however, extended to 14 days by the Criminal Justice Act $2003,{ }^{30}$ and then to 28 days by the Terrorism Act $2006 .{ }^{31}$ Under s. 25 of the 2006 Act the 28-day maximum was to endure for just one year, ${ }^{32}$ unless the Secretary of State made an order disapplying the sunset clause in that section. In 2007 and 2008 the Secretary of State did make such an order, thereby retaining the 28-day maximum for a further 12 months on each occasion. ${ }^{33}$ In June 2008 the government won a vote in the House of Commons to allow the Home Secretary to order an extension of the maximum detention period to 42 days, ${ }^{34}$ but in October 2008 this proposal was heavily defeated in the House of Lords ${ }^{35}$ and the government announced that it would drop it from the Counter-Terrorism Bill but keep it in reserve for future use if necessary. ${ }^{36}$ The Counter-Terrorism Act 2008 does not therefore affect the maximum precharge detention period, which remains at 28 days.

\section{What the ECHR says about pre-charge detention}

The ECHR engages in some way with the issue of detention in a number of articles, but at no point is it specific as to the permitted duration of detention, whether pre-charge or post-charge. Perhaps for that reason the ECHR has not often been directly invoked during

26 Ss. 29(3) and 36(3). The UK government was then able to withdraw its notice of derogation on 19 February 2001. For copies of the UK's declarations concerning the ECHR see the website of the Netherlands Institute of Human Rights: http://sim.la.uu.nl/SIM/library.

27 A v Secretary of State for the Home Department [2005] 2 AC 68, a decision by $8 \mathrm{v} 1$.

28 Av UK App. No. 3455/05, 19 February 2009, a unanimous judgment of the Grand Chamber.

29 See, generally, J Wadham, H Mountfield, A Edmundsen and C Gallagher, Blackstone's Guide to the Human Rights Act 1998 4th edn (Oxford: Oxford University Press 2007), pp. 44-5.

30 S. 306, which inserts new paras (3A) and (3B) into the Terrorism Act 2000, Sch. 8.

31 MPs voted by 322 to 291 against the government's proposal for 90 -day detentions and by 323 to 290 in favour of 28-day detentions: HC Debs, vol. 439, cols 325-85 (9 November 2005).

32 If it were to lapse, the maximum detention period would revert to 14 days.

33 Terrorism Act 2006 (Disapplication of Section 25) Orders 2007 (SI 2007/2181) and 2008 (SI 2008/1745). The 28-day maximum will now disappear on 25 July 2009 unless a further order is made disapplying s. 25. A draft of such an order has already been published.

34 This was during the report stage of the Bill on 11 June 2008: HC Debs, vol. 477, cols 312-400.

35 HL Debs, vol. 704, cols 491-541 (13 October 2008); the vote, during the committee stage of the Bill, was 309 to 118 against extending the maximum pre-charge detention period beyond 28 days, a majority of 191 .

36 The then Home Secretary, Jacqui Smith, announced two hours after the vote in the Lords: "I have prepared a new Bill to enable the police and prosecutors to do their work - should the worst happen, and should a terrorist plot overtake us and threaten our current investigatory capabilities . . . The Counter-Terrorism (Temporary Provisions) Bill now stands ready to be introduced if and when the need arises ... I will place a copy of the new Bill in the Library of the House." HC Debs, vol. 480, col. 624 (13 October 2008). 
parliamentary debates on the permitted maximum detention period. ${ }^{37}$ We can infer from the jurisprudence of the European Court of Human Rights, however, that the permitted duration may differ depending on the type and nature of the detention in question. ${ }^{38}$ Article 5(1) confers on everyone the right to liberty and security of the person, but it then sets out a list of situations in which a person can be deprived of liberty if this is done in accordance with a procedure prescribed by law. One of the situations listed, in Article $5(1)(c)$, refers to the arrest or detention of persons for the purpose of bringing them before a competent legal authority on reasonable suspicion of having committed an offence, and Article 5(3) goes on to state that any such person "shall be brought promptly before a judge or other officer authorised by law to exercise judicial power and shall be entitled to trial within a reasonable time or to release pending trial". 39 In addition, by Article 5(4), anyone so arrested or detained "shall be entitled to take proceedings by which the lawfulness of his detention shall be decided speedily by a court and his release ordered if the detention is not lawful". 40

At no point does the Convention suggest that the time at which a person is charged with an offence should influence the lawfulness of his or her detention. In fact the only occasion on which Article 5 refers to a person being charged is in paragraph (2), which gives everyone who has been arrested the right to be informed promptly of the reasons for the arrest "and of any charge against him". In the eyes of the European Court of Human Rights the main significance of someone being charged is that it triggers the application of the specific fair trial guarantees provided for in Article 6 of the Convention. ${ }^{41}$ Indeed it seems clear that the main reason for the absence of any reference to the concept of "charge" in the body of Article 5(1) is that the Convention was trying to distinguish between liberty rights and trial rights: the charging of a detainee was not deemed to be relevant to the permitted duration of the person's detention. Moreover, even within Article 6 the term "charge" has an autonomous meaning that is not necessarily tied to any meaning ascribed to the term within a national legal system. This was made clear by the European Court of Human Rights in

37 In the debate on the report stage of the Terrorism Bill in the House of Commons on 9 November 2005 the then Home Secretary, Charles Clarke, said that he had certified that the Bill was fully compatible with the European Convention, but at no point did he go into detail on Article 5, nor was he pressed on this point by any other MP, except William Cash, who argued that the Law Lords would declare the legislation to be incompatible with the Human Rights Act: see HC Debs, vol. 439, col. 376. In the debate on the second reading of the Counter-Terrorism Bill in the House of Lords on 8 July 2008 Lord Lester of Herne Hill said that the Home Secretary's argument for a 42-day maximum would not be likely to convince either our domestic courts or the European Court that it was compatible with the fundamental right to liberty in Article 5 of the ECHR (HL Debs vol. 703, col. 654), and in the debate on the committee stage of the Bill on 13 October 2008 Lord Lester urged the government minister to say how he would answer "the view of all independent legal commentators and of the Joint Committee on Human Rights that there will be serious breaches of the convention without a derogation". Lord West of Spithead replied that he did not intend to go into that in detail: "I simply say that I see nothing at all in what we are doing here that goes against the ECHR. There would have to be a challenge through the courts to show that but I do not believe that it does; I think that we have all the right safeguards in place.” (HL Debs vol. 704, col. 537).

38 I have examined different types of detention, and their consequences under the European Convention, in "The detention of terrorist suspects in Great Britain and Northern Ireland" (2009) 43 U Richmond L Rev 927. Detention in a small cell in a police station, for example, could become "degrading treatment" in breach of Article 3 of the ECHR much sooner than it might if the detention were to occur in a prison, with all the facilities normally available there.

39 A case in Strasbourg brought from Northern Ireland has established that the judge or other officer before whom a detainee is first brought does not have to be someone who has the power to order the person's release on bail: McKay v United Kingdom (2007) 44 EHRR 41.

40 Articles 6, 8 and 11 might also be relevant, but they are outside the scope of this essay.

41 C Ovey and R White, Jacobs and White: The European Convention on Human Rights 4th edn (Oxford: Oxford University Press 2006), pp. 161-2. 
Deweer v Belgium ${ }^{42}$ where, relying upon earlier commission decisions, ${ }^{43}$ it defined a "charge" as "the official notification given to an individual by the competent authority of an allegation that he has committed a criminal offence". ${ }^{44}$ In the United Kingdom the police regularly put allegations to a detainee as part and parcel of the normal interrogation process and this may be enough to bring into play the rights conferred by Article 6 even though the police do not formally "charge" the detainee until they have accumulated enough information to be at the very least 50 per cent confident that they will be able to secure a conviction. ${ }^{45}$

The right conferred by Article 5(2) is less extensive than that conferred by Article $6(3)(a)^{46}$ and has been interpreted by many commentators as being focused on the supply of reasons for the arrest of detention. ${ }^{47}$ Notification of any charge is required only if such a charge is forthcoming. Cases reaching the European Court from Northern Ireland have helped to clarify that the reasons given to the detainee for his or her arrest can be scant, provided only that the surrounding circumstances of the arrest, or the questions later put to the detainee (provided they are put promptly), are sufficient to allow him or her to deduce the reasons for the arrest. ${ }^{48}$ While simply telling a detainee that he or she is being detained on suspicion of involvement in terrorism may not of itself be enough to satisfy Article 5(2), a full charge-sheet certainly does not have to be presented to the detainee. It is enough for the detainee to be informed indirectly of what it is that he or she is reasonably suspected of having done. ${ }^{49}$ The court would certainly approach any such question bearing in mind the context involved, namely the threat of terrorism. In Chraidi v Germany, for example, the court tolerated pre-trial (not pre-charge) detention lasting for five years and almost six months in a case where the applicant was accused of having prepared a bomb attack on a discotheque in Berlin frequented by members of the US armed forces. ${ }^{50}$

The wording of Article 5(3), as has often been pointed out, ${ }^{51}$ is far from ideal. On the one hand, it clearly aims to ensure that people who are arrested or detained on reasonable suspicion of having committed an offence are given an opportunity to convince a judge

42 (1979-80) 2 EHRR 439. See also Eckle v Germany (1983) 5 EHRR 1, para. 73.

43 E.g. Neumeister v Austria (1979-80) 1 EHRR 91 (decision of 27 June 1968). See, generally, S Trechsel, Human Rights in Criminal Proceedings (Oxford: Oxford University Press 2005), pp. 31-6.

44 Neumeister v Austria (1979-80) 1 EHRR 91, para. 46.

45 See e.g. Magee v UK (2001) 31 EHRR 45, where the conditions endured by the detainee in Castlereagh holding centre in Belfast prior to his being charged (when coupled with the crucial fact that there was denial of access to a solicitor) were held to have contributed to the overall unfairness of his trial.

46 See K Reid, A Practitioner's Guide to the European Convention on Human Rights 3rd edn (London: Sweet \& Maxwell 2007), p. 140. Article 6(3)(a) reads: "Everyone charged with a criminal offence has the following minimum rights: (a) to be informed promptly, in a language which he understands and in detail, of the nature and cause of the accusation against him."

47 Reid, A Practitioner's Guide, n. 46 above, pp. 510-13.

48 Fox, Campbell and Hartley v United Kingdom (1990) 13 EHRR 157, where it was held that the detainee must be told "the essential legal and factual grounds for his arrest" (para. 40); Murray (Margaret) v United Kingdom (1996) 22 EHRR 29. In both cases the European Court reversed the European Commission on this point. See, too, Kerr $\mathrm{v}$ United Kingdom App. No. 40451/98, decision on inadmissibility, 7 December 1999.

49 See e.g. Murray v UK (1995) 19 EHRR 193, paras 76-7; Dikme v Turkey App No 20869/92, decision of 11 July 2000, para. 56; Egmezv Cyprus (2002) 34 EHRR 29, paras 85-6; all cited in Trechsel, Human Rights, n. 43 above, p. 461. Trechsel describes the ECHR jurisprudence as "far from ideal" because it could leave a detainee guessing as to why he or she has been detained.

50 (2006) 47 EHRR 47. The court partly justified its decision by saying there were "difficulties intrinsic to the prosecution of offences committed in the context of international terrorism" (para. 55).

51 See e.g. D Harris, M O'Boyle, E Bates and C Buckley, Law of the European Convention on Human Rights 2nd edn (Oxford: Oxford University Press 2009) p. 173. 
that, pending the determination of their guilt of that offence, they should not be held in custody. To that extent the paragraph is a provision about bail, as its last few words strongly imply. ${ }^{52}$ On the other hand, the paragraph seems to confer a right to be released (whether on bail or not) if a trial cannot occur within a reasonable time. But the European Court has for long shied away from this second interpretation, even if it has not always explained very clearly why this is so. In Wemhoff v Germany, for instance, the Court said, in what was only its seventh decision, ${ }^{53}$ that Article 5(3) should not be read literally because that would mean that by releasing a detainee a member state could evade its obligation to try that person within a reasonable time (although Article 6, of course, still confers the right to a fair and public hearing within a reasonable time). It added:

The Court is quite certain that such an interpretation would not conform to the intention of the High Contracting Parties. It is inconceivable that they should have intended to permit their judicial authorities, at the price of release of the accused, to protract proceedings beyond a reasonable time ... It is thus mainly in the light of the fact of the detention of the person being prosecuted that national courts, possibly followed by the European Court, must determine whether the time that has elapsed, for whatever reason, before judgment is passed on the accused has at some stage exceeded a reasonable limit, that is to say imposed a greater sacrifice than could, in the circumstances of the case, reasonably be expected of a person presumed to be innocent.

In other words it is the provisional detention of accused persons which must not, according to Article 5(3), be prolonged beyond a reasonable time . . .54

The court confirmed this approach to Article 5(3) in its very next decision, Neumeister v Austria, ${ }^{55}$ where it said that "the purpose of the provision under consideration is essentially to require [the detainee's] provisional release once his continuing detention ceases to be reasonable". In Schiesser v Switzerland the court expanded upon this by saying:

under Article 5 para. 3 there is both a procedural and a substantive requirement. The procedural requirement places the "officer" under the obligation of hearing himself the individual brought before him . . . ; the substantive requirement imposes on him the obligations of reviewing the circumstances militating for or against detention, of deciding, by reference to legal criteria, whether there are reasons to justify detention and of ordering release if there are no such reasons. ${ }^{56}$

In none of the cases on Article 5(3) has the European Court stated that a delay in charging the detainee is itself a ground for finding the detention to be unjustifiable.

Article 5(4) of the Convention has a broader remit than Article 5(3): it applies to all persons who have been deprived of their liberty by arrest or detention (not just those arrested or detained on reasonable suspicion of having committed an offence) and it

52 "Release may be conditioned by guarantees to appear for trial."

53 (1979-80) 1 EHRR 55, judgment of 27 June 1968.

54 Ibid. paras 4-5. Note the use of the word "prosecuted" in the fifth line of this quotation, which, taken together with the word "accused" in the 11th line, implies that Article 5(3) was intended to apply to people who (in UK terms) have already been charged with an offence.

55 (1979-80) 1 EHRR 91, judgment of 27 July 1968, “The Law”, para. 4

56 (1979-80) 2 EHRR 417, para. 31, citing Ireland v United Kingdom (1979-80) 2 EHRR 25, para. 199, although that paragraph does not in fact deal specifically with the nature of the substantive obligation in question. The statement in Schiesser was later approved in e.g. De Jong, Baljet and Van den Brink v The Netherlands (1986) 8 EHRR 20, para. 47, and the latter was in turn approved in Aquilina v Malta App. No. 25642/94, judgment of 29 April 1999. 
confers the right on all such persons to have the lawfulness of their detention decided speedily by a court and to be released if their detention is found not to be lawful. ${ }^{57}$ There is obviously an overlap between the two paragraphs in that everyone who can claim the right protected by Article 5(3) can also claim the right protected by Article 5(4), but there are still important differences between the two provisions. Article 5(3) requires the detainee to be brought "promptly" before a judge or other judicial officer, while Article 5(4) speaks of the right to take proceedings by which the lawfulness of the detention shall be decided "speedily" by a court. Article 5(3) envisages that the detainee may be kept in custody until a reasonable time has elapsed for a trial to take place, while Article 5(4) requires the detainee to be released if the detention is found on any ground to be unlawful. And Article 5(3) does not imply that a detainee who seeks to be released on bail should have the full panoply of rights that a detainee who relies on Article 5(4) might claim: the European Court has accepted that both provisions "must be understood to require the necessity of following a procedure that has a judicial character although that procedure need not necessarily be identical in each of the cases where the intervention of a judge is required". 58 The particular judicial character required by Article 5(4) has to be appropriate to the kind of deprivation of liberty in question, but should if possible approximate the basic requirements of a fair trial laid down by Article 6(1) of the Convention. ${ }^{59}$ As the Court said in Schöps v Germany:

in view of the dramatic impact of deprivation of liberty on the fundamental rights of the person concerned, proceedings conducted under Article 5 \ 4 of the Convention should in principle also meet, to the largest extent possible under the circumstances of an ongoing investigation, the basic requirements of a fair trial, such as the right to an adversarial procedure. While national law may satisfy this requirement in various ways, whatever method is chosen should ensure that the other party will be aware that observations have been filed and will have a real opportunity to comment thereon. ${ }^{60}$

In its recent decision concerning detention without trial under the Anti-terrorism, Crime and Security Act 2001 in the United Kingdom, the European Court emphasised that "in view of the dramatic impact of the lengthy - and what appeared at that time to be indefinite - deprivation of liberty on the applicants' fundamental rights, Article 5(4) must import substantially the same fair trial guarantees as Article 6(1) in its criminal aspect". 61 The House of Lords has now followed that decision in a case concerning control orders issued under the Prevention of Terrorism Act 2005, ${ }^{62}$ but one cannot necessarily deduce from that that, in a situation where the maximum detention period is 28 days and police investigations are ongoing into whether or not there is enough evidence to charge the detainee, the same strict adherence to the demands of Article 6(1) will be required. The Terrorism Act 2000

57 See, generally, Reid, A Practitioner's Guide, n. 46 above, pp. 532-41. See too p. 456, in the section on pre-trial detention, where Reid observes that complying with Article 5(4) is not enough to ensure compliance with Article 5(3) because the latter requires the review to be automatic, not self-generated, citing Aquilina v Malta, n. 56 above, para. 53. This point was also made in Ireland v United Kingdom, n. 56 above, para. 199.

58 Brannigan and McBride v UK (1993) 17 EHRR 539, at para. 58, citing Schiesser v Switzerland, (1979-80) 2 EHRR 417, para. 30; Huber v Switzerland App No 12794/87, judgment of 23 October 1990, paras. 42-3; De Wilde, Ooms and Versyp v Belgium (1979-80) 1 EHHR 373, para. 78; Sanchez-Reisse v Switzerland (1986) 9 EHRR 71, para. 51; and Lamy v Belgium App No 10444/83, judgment of 30 March 1989, para. 28.

59 Reid, A Practitioner's Guide, n. 46 above, pp. 535-6.

60 App. No. 25116/94, judgment of 13 February 2001, citing Brandstetter v Austria App. No. 11170/84, judgment of 28 August 1991, pp. 27-8, para. 67.

61 A v UK App. No. 3455/05, 19 February 2009, para. 217.

62 Secretary of State for the Home Dept $\mathrm{v}$ AF [2009] UKHL 28, a unanimous decision of nine Law Lords. 
does allow a judge to exclude the detainee or his or her representative from actually being present at any part of the hearing, ${ }^{63}$ and even after the House's recent decision there is still scope for that to occur, especially if, as the Parliamentary Joint Committee on Human Rights has proposed, ${ }^{64}$ "special advocates" are appointed to assist the detainee. ${ }^{65}$

Article 5, in short, requires the detention of persons reasonably suspected of crimes to be both lawful and reasonable. But the European Court of Human Rights has not given any indication of how many hours or days of detention would in general be reasonable, certainly not as regards the period of detention preceding the laying of any charge against the detainee. Nor has it stipulated that during ongoing police investigations into a crime persons reasonably suspected of involvement in that crime but not yet charged have to be accorded the full panoply of Article 6(1) rights.

\section{The views of experts on 28-day detentions}

In 2003 Parliament's Joint Committee on Human Rights thought that the proposal in the Criminal Justice Bill to extend the maximum detention period for terrorist suspects from seven to 14 days was not in itself a breach of Article 5. ${ }^{66}$ It suggested that 14 days would not be arbitrary since there were arrangements to ensure that there were sufficient grounds for detaining the person and that the detention was proportionate both in the period of detention and the conditions of detention. Presumably, the Committee meant that the detention was proportionate relative to the threat being faced by the country. But the Committee did draw Parliament's attention to the fact that, because the proposed Bill envisaged detention being extended on the basis of information not disclosed to the detainee or to any legal representative of the detainee, there was a potential for a lack of fairness. ${ }^{67}$

In 2005, when the proposal was made in the Terrorism Bill to extend the maximum precharge detention period from 14 days to 90 days, the Joint Committee concluded that this would breach Article 5 because it would be "clearly disproportionate" and "accompanied by insufficient guarantees against arbitrariness". The Committee also felt that such an extension "risked leading to independent breaches of Article 3 ECHR, and to the inadmissibility at trial of statements obtained following lengthy pre-charge detention". ${ }^{68}$ In fact the Committee went on to state that, despite the relevant legal standards not being "very concrete", the proportionality case for any increase to the current 14-day limit - even to 28 days - had not been made out on the evidence. ${ }^{69}$ It did not, however, rule out the possibility that such evidence might be produced in the future. ${ }^{70}$

In November 2005 no less a figure than Louise Arbour, the then UN High Commissioner for Human Rights, wrote to the UK Permanent Representative to the UN Office in Geneva expressing "grave concern" over how the rights in the ECHR (and in the

63 Sch. 8, para. 33(3). See, too, para. 34(4).

64 2nd Report of 2007-08, HL 23/HC 156, paras 88-9. See, too, the text at n. 75 below.

65 In R (Roberts) v Parole Board [2005] 2 AC 738 the Law Lords held, by 3 v 2 (Lords Bingham and Steyn dissenting), that the Parole Board was able, within the powers granted by the Criminal Justice Act 1991, and compatibly with Article 5 of the ECHR, to withhold material relevant to the appellant's parole review from the appellant's legal representatives and to disclose that material instead to a specially appointed advocate, who would represent the appellant, in the absence of the appellant and his legal representatives, at a closed hearing before the Parole Board.

66 11th Report, 2002-03, HL 119/HC 724, para. 101.

67 Ibid. para. 105.

68 3rd Report of 2005-06, HL 75-I/HC 561-I, para. 87.

69 Ibid. para. 92 (emphasis added).

70 Ibid. 
International Covenant on Civil and Political Rights) would be protected if pre-charge detention were extended to 28 days in the United Kingdom. But the High Commissioner did not make a detailed case substantiating her points and in a written Ministerial Statement issued six weeks later the Home Secretary said he was satisfied that 28-day detentions did not breach the country's international human rights obligations. ${ }^{71}$ The Joint Committee again disagreed, setting out its reasoning at some length. ${ }^{72}$ The Home Affairs Select Committee, on the other hand, accepted the need to move to a 28 -day maximum ${ }^{73}$ and later repeated that it may be necessary to move beyond the 28 -day maximum. ${ }^{74}$ Undaunted, the Joint Committee continued to repeat its views in a number of subsequent reports, relying on its interpretation of the European Court's jurisprudence based around Articles 5(1), (2), (3) and (4) of the Convention. ${ }^{75}$ Nevertheless, as already noted, Parliament approved of 28-day detentions and the relevant section of the Terrorism Act 2006 (s. 23) came into effect on 25 July $2006 .{ }^{76}$

Section 36 of that Act, replacing s. 126 of the Terrorism Act 2000, requires the Secretary of State to appoint a person to review the operation of both the Terrorism Act 2000 and Part 1 of the 2006 Act, and Lord Carlile of Berriew QC has undertaken that task to date. ${ }^{77}$ In his reports on the operation of the Acts during 2007 and 2008, he concludes that overall the provisions were "fit for purpose", 78 but he admits that he has not conducted a detailed analysis of the system whereby judges supervise 14-28 day detentions. ${ }^{79}$ He notes that he has not been asked to do this and that it would in any event be difficult for him to do so in any meaningful way without becoming "embedded" in some cases from arrest to verdict. He adds that he expects in due course to see cases in which the current maximum of 28 days will prove inadequate. ${ }^{80}$

In April 2008 the newly created Equality and Human Rights Commission (EHRC) published legal advice from Rabinder Singh QC and Professor Aileen McColgan on the legality of the proposal for a maximum pre-charge detention period of 42 days. The report concluded that 42-day detentions would be likely to result in breaches of Articles 5(1), (2), (3) and (4) of the ECHR, and also of Articles 3, 6 and 14, ${ }^{81}$ and many of the arguments

71 HC Debs, 9 January 2006, col 1WS.

72 24th Report of 2005-06, HL 240/ HC 1576, passim.

73 4th Report of 2005-06, HC 910-I.

74 1st Report of 2007-08, HC 43-I, paras 6-76.

75 See 2nd Report of 2007-08, HL 23/HC 156, passim; 9th Report of 2007-08, HL 50/HC 199, paras 2-21; 20th Report of 2007-08, HL 108/HC 554, paras 6-36; 21st Report of 2007-08, HL 116/HC 635, paras 3-44; 25th Report of 2007-08, HL 132/HC 825, passim; 30th Report of 2007-08, HL 172/HC 1077, paras 7-88.

76 Terrorism Act 2006 (Commencement No 2) Order 2006.

77 Lord Carlile first reported on the UK's anti-terrorism laws in 2001. In the second reading debate of the 2006 Terrorism Bill in the House of Lords he expressed support for the 28-day compromise but hinted that he could have supported a longer maximum: "Twenty-eight days offers an improvement, although a modest one, in terms of public safety ... I hope that time will confirm the democratic wisdom of another place" (HL Debs, vol. 675, col. 1436; 21 November 2005). In the debate on the committee stage of the 2008 Bill he claimed that a 42-day maximum pre-charge detention period would be compatible with the ECHR (HL Debs vol. 704, cols 504 and 506; 13 October 2008).

78 Report on the Operation in 2007 of the Terrorism Act 2000 and of Part 1 of the Terrorism Act 2006 (June 2008), para. 283, and Report on 2008 (June 2009), para. 238. Both reports are available on the Home Office website: www.homeoffice.gov.uk. In 2008 only one person was released after being detained for longer than 14 days, and that was after 19 days: Report on 2008, para. 128.

79 Report on 2007, para. 103.

80 Report on 2007, para. 109; Report on 2008, para. 128.

81 The 115-page document is available on the EHRC's website: www.equalityhumanrights.com. 
raised in support of this view could apply just as much to 28-day detentions as they do to 42-day detentions. In particular, the authors relied on Lamy v Belgium 82 and Garcia Alva v Germany 83 to claim that "hearings in the absence of the accused, and/or withholding of information from detainees, give rise to difficulties under Article 5(4) of the Convention, and may prevent a hearing being adequate for the purposes of Article 5(3)". 84 They also appeared ${ }^{85}$ to endorse the view of the Joint Committee that hearings to decide if detention should be extended would only be compatible with Article 5(4) if the police or prosecution were required to satisfy the court "that there is material giving reasonable grounds to believe that the suspect has committed a terrorism related offence in the first place". 86 The advice conceded, however, that the House of Lords has already decided that at hearings for a warrant of further detention the police are entitled to withhold from the suspect the line of questioning the police intend to put to the detainee. ${ }^{87}$

The Committee on Legal Affairs and Human Rights of the Parliamentary Assembly of the Council of Europe also weighed in with a report in September 2008. ${ }^{88}$ This expressed "serious doubts" about the ECHR-compatibility of the proposed 42-day detention regime, yet it acknowledged that "the Convention does not require a formal charge to be taken within a specific time, but only sets out procedural requirements that must be fulfilled during any detention prior to conviction". ${ }^{89}$ It did not specifically condemn 28 -day detentions.

\section{The arguments for incompatibility}

The arguments which stand out as having some real plausibility in terms of the incompatibility of 28-day detentions with Article 5 are those based on disproportionality and the lack of a fully adversarial procedure for granting extensions to initial detention periods. But in fact none of them is completely watertight. Those focused on disproportionality ignore the reality that the Convention does not in general concern itself with laws in the abstract but only with how they are applied in practice. ${ }^{90}$ When faced with a challenge to a 28-day detention, the European Court of Human Rights will ask itself whether on the facts of the case before it the applicant's rights under Article 5 have been violated, not whether the law itself is inherently incompatible. In such a context, both the likelihood of terrorism occurring in general, and the possible consequences if it were to occur, are not entitled to be taken into account, for all that matters is whether it can be shown that there are reasonable grounds for suspecting the particular applicant's involvement in terrorism. A general "top level" security threat would of itself not be enough to justify the continued detention of anyone in the absence of information reasonably linking that person to a suspected terrorist cell, plot or action. Conversely, even if the general security level were extremely low, reasonable suspicion that a particular person was involved

82 (1989) 11 EHRR 529.

83 (2003) 37 EHRR 12.

84 EHRC document, n. 81 above, para. 45.

85 Ibid. para. 64.

86 9th Report of 2007-08, HL 50/HC 199, para. 94. See also para. 87, cited by Singh and McColgan, EHRC document, n. 81 above, at para. 58.

87 Ward v Police Service of Northern Ireland [2007] 1 WLR 3013.

88 See http://assembly.coe.int/Main.asp?link=/Documents/WorkingDocs/Doc08/EDOC11725.htm.

89 Ibid. para. 31.

90 Cf. the European Court of Human Rights in Fox, Campbell and Hartley v UK (1990) 13 EHRR 157, para. 31: "The Court's task, however, is not to review the impugned legislation in abstracto but to examine its application in these particular cases." 
in terrorism could be enough to justify his or her initial, and indeed further, detention.

A variant of the main disproportionality argument is that 28-day detention somehow undermines the need for the existence of "reasonable suspicion" in relation to the initial detention. There are some (very weak) dicta in the judgment of the European Court of Human Rights in Fox, Campbell and Hartley v UK which might suggest that the longer detention continues the more doubt is inevitably cast on the reasonableness of the initial detention. ${ }^{91}$ But this assumes that the reasonableness of suspicion is a function of how long it takes to substantiate that suspicion, when in fact it is a function of the likelihood that the suspicion will turn out to be well-grounded. Moreover, Fox, Campbell and Hartley v UK was primarily concerned with whether arrests founded on mere suspicion (as opposed to reasonable suspicion) were compatible with Article 5(1)(c) of the Convention, so anything said by the Court in relation to any part of Article 5(3), including the meaning of the word "promptly" in that paragraph, must be taken as not necessarily authoritative. Nor is it right that the test for authorising extensions to initial detention in UK law is disproportionately low. Just because detention is extended, it does not follow that the evidence justifying it has to get proportionately stronger. Detention may need to be longer not only because there are stronger grounds than before for suspecting the detainee's involvement, but also because there are more grounds for that suspicion that require to be investigated. It is the time required to check those additional grounds that justifies the detention.

It does remain the case, though, on one reading of the current legislation, that at a hearing for a warrant of further detention the judge does not need to be satisfied that the original arrest was based on reasonable suspicion at all. The basis for such a reading is a provision in the Terrorism Act 2000 which says that a detained person "shall be deemed to be in legal custody throughout the period of his detention". ${ }^{2}$ But in a recent case the Divisional Court of Northern Ireland has held that that provision does not excuse a court from examining the legality of the detainee's original arrest. ${ }^{93}$ The court found support for this view in Article 5(3) of the Convention but, with respect, more appropriate support seems to be available in Article 5(4). As noted above, Article 5(3) primarily regulates how quickly a detained person should be brought before a judge for a decision to be taken on whether to grant release on bail. Article 5(4) has a broader scope in that it guarantees to every person who has been arrested or detained (on whatever grounds) the right to take proceedings by which the very lawfulness of the detention shall be decided speedily by a court. Admittedly, Article 5(4) does not expressly require the initial arrest of the detainee to be checked in such proceedings, but in practice a domestic court considering the lawfulness of detention is very unlikely to interpret the word "detention" in Article 5(4) narrowly, and so is the European Court. "Detention" in Article 5(4) will be taken as referring to the detention experienced since the moment of the arrest, not to any specific period arising after the arrest.

91 Fox, Campbell and Hartley v UK (1990) 13 EHRR 157, para. 35: "The fact that all the applicants, during their detention, were questioned about specific terrorist acts, does no more than confirm that the arresting officers had a genuine suspicion that they had been involved in those acts, but it cannot satisfy an objective observer that the applicants may have committed these acts." But the commission explicitly accepted that in terrorist cases the "reasonableness" of the suspicion underpinning detention can be of a lower standard than in nonterrorist cases, because the authorities cannot disclose their confidential sources "or even facts which could be susceptible of indicating such sources or their identity" (para. 34).

92 Sch. 8, para. 5.

93 In re Colin Duffy's Application [2009] NIQB 31. The court left to a future hearing the question whether a declaration of incompatibility should be issued in relation to provisions in the Terrorism Act 2000. It is submitted here that, as in Secretary of State for the Home Department $\mathrm{v}$ AF [2009] UKHL 28, the provisions can in fact be "read down" under s. 3 of the Human Rights Act 1998 so as to be rendered compatible with Convention rights. 
A 28-day pre-charge detention period may also be regarded as disproportionate in that there are other means at the disposal of the prosecution for dealing with suspected terrorists, but this in turn depends on whether those other means are compatible with Convention rights. To date at least four such alternatives have been canvassed, including by the government itself: ${ }^{94}$ (a) lowering the threshold for pressing charges against a detainee; 95 (b) allowing detainees to be held on "holding charges" while more serious allegations are investigated; 96 (c) charging detainees not for acts that have already been committed but for "acts preparatory to terrorism"; and (d) allowing detentions to be charged on the basis of "intercept evidence" even though such evidence may not later be admissible at a subsequent trial. At first glance these suggestions may collectively present a strong case in favour of concluding that 28-day detentions breach Article 5(3) because they are unnecessary. But in relation to the first two options it has to be remembered that the standard for pressing charges can never be reduced to below that of "reasonable suspicion" and that to ensure that the suspect does not abscond the offence charged still has to be serious enough to warrant deprivation of liberty pending trial. As for the last two options, they both presuppose that after being charged the detainee can be questioned further about his or her past or planned involvement in particular activities. At present, however, post-charge questioning is not permitted under English law, because of the risk that it might make the overall trial process unfair under Article 6 of the Convention. It is true that Part 2 of the Counter-Terrorism Act 2008 makes provision for post-charge questioning in all parts of the United Kingdom for periods of up to 48 hours at a time, and that the availability of this power, if the relevant sections are ever commenced, may well make it more difficult for the police to convince a judge that extended pre-charge detention is necessary in a particular case. Even then, though, in some cases there may still be insufficient grounds of suspicion to meet the standard required for the laying of any charge, nor may there be any intercept evidence available, so prolonged pre-charge detention may still be genuinely necessary for a longer period.

Incompatibility arguments focused on the lack of a fully adversarial procedure for granting extensions to initial detention periods presuppose that the police have failed to grant the detainee the range of "fair trial" guarantees protected by Article 5(4). The House of Lords, in its recent nine-judge decision on the regime for issuing control orders, has made it clear that these guarantees will not be satisfied if the controlee in question is not given sufficient information on the case against him or her to enable effective instructions to be given to the special advocate appointed to assist the controlee. ${ }^{97}$ One can deduce from this that the information required to be given to detainees, whose liberty is at stake in a way that goes beyond what controlees have to face, would need to be even more detailed. But if that information is supplied, if the detainee is granted his or her statutory rights of access to a solicitor and to medical examination, and if the police can show that the investigation in question is being conducted diligently and expeditiously, then Article 5(4) will not be breached.

94 Home Office Consultation Paper, Options for Pre-charge Detention in Terrorism Cases (July 2007). See, too, the report compiled by Jago Russell for the NGO Liberty, Charge or Release: Terrorism pre-charge detention - comparative law study (November 2007). Unfortunately, neither of these reports adequately grapples with the reality that in criminal justice systems based on the French model the concept of being "inculpated" (inculpé) does not carry the same significance as being "charged" in the British and Irish criminal justice systems.

95 This is already allowed under the Code for Crown Prosecutors in England and Wales, para. 3.3. See the Joint Committee on Human Rights' 24th Report of 2005-06, HL 240/HC 1576, paras 122-9.

96 This alternative was rejected by the Joint Committee: 24th Report of 2005-06, HL 240/HC 1576, paras 139-42 (endorsing the view of the Crown Prosecution Service, which saw it as an abuse of state power).

97 Secretary of State for the Home Department $\mathrm{v}$ AF [2009] UKHL 28. 


\section{Conclusion}

It seems, on the basis of the information and analysis presented above, that Article 5 of the Convention envisages pre-charge detention lasting for a reasonable time, and that what is reasonable can depend on a variety of factors, including not only the length of the period in question but also the offence of which the detainee is reasonably suspected, the complexity of the investigation relating to that offence, the ability of the detainee to provide information relating to the investigation, the conditions under which the detainee is held, and the accessibility of the detainee to communication with the outside world, in particular with a legal adviser. The onus, admittedly, is on the authorities that want to prolong detention for as long as 28 days to show that, in all the circumstances, this is justified. If the High Court judge considering whether to extend detention beyond 14 days is satisfied that the pre-conditions laid down in the Terrorism Act 2006 have been met, if the detainee is provided with an Article 5(4)-compliant opportunity to challenge the reasons put forward for the extended detention, and if the detaining authorities have no other course of action available to them to determine whether or not the detainee deserves to be charged with a terrorist offence, then, difficult though it may be to have to concede the point, 28-day detentions are probably compatible with the European Convention.

This position will not change unless and until the European Court of Human Rights asserts, as it has done in relation to the time that can elapse before a detained person has to be initially brought before a judge or other officer authorised by law to exercise judicial power, ${ }^{98}$ that there is a notional maximum period that cannot be exceeded before a detainee is charged with an offence. Given the difficulties inherent in defining what "charged" means across all 47 Council of Europe states, the court is unlikely to make that assertion. Alternatively, the UK's new Supreme Court could decide that the values of English common law require there to be a stated maximum for pre-charge detention periods, even if Convention values do not. But the fact that parliamentarians have argued long and hard over what that maximum should be is very likely to discourage judges from rushing in where angels fear to tread. The Supreme Court will see the matter as one pre-eminently suitable for legislative rather than judicial regulation. Of course, if there is to be a British Bill of Rights and Responsibilities, which both main political parties are now advocating, ${ }^{99}$ perhaps the right not to be detained for longer than, say, 14 days before being charged with an offence could be made a part of it.

98 See Brogan v UK, n. 25 above.

99 See the government's Green Paper, Rights and Responsibilities: Developing our constitutional framework Cm 7577 (London: HMSO March 2009). 